\title{
THE CAPTIVE KHAN AND THE CLEVER DAUGHTER-IN-LAW
}

\author{
Yuri Berezkin, Evgeny Duvakin
}

\begin{abstract}
The Aarne-Thompson-Uther index contains rich data on the tale repertoire of the main areas of Eurasia and North Africa, but it is still Eurocentric, and does not reflect many widespread tale-types that are not registered in Europe or rarely found across the region. We have revealed several plots of such kind. Their distribution seems to point to the eastern part of the Great Steppe as the area of their origin. Later on waves of nomads might have brought these plots to Europe. In this article, two of them are analysed in detail: The Encoded Message (that includes rather different versions) and The Big Bull. Both find correspondences in Balto-Finnic traditions, which allows us to discuss them in the context of previously unrecognised or poorly studied parallels between the Caucasus and Northern Europe. The approximate date of these links is the second part of the first millennium A.D.
\end{abstract}

Keywords: cultural and historical links, Eurasian steppe belt, folklore databases, folktales

It is well known that the Aarne-Thompson-Uther index of The Types of International Folktales (Aarne 1910; Aarne \& Thompson 1961; Uther 2004) has a whole set of serious drawbacks. The crucial one is not the inconsistence in classification (it is inevitable due to the nature of the material), but combining under the same number of such episodes that are not tied inflexibly to each other and have different areal distribution (Berezkin 2015a: 62-64; 2015b: 154-159). There is no way to ascertain whether a cited narrative of a certain type contains all of the listed episodes and what episodes the text exactly includes if you do not have access to the original publications. It does not mean that the ATU index is quite useless in searching for parallels, but it implies that this system is not as efficient as it could be.

The main reason lies in the Eurocentric character of The Types of International Folktales. On the one hand, ATU's power to classify the folklore of Sub-Saharan Africa, Siberia, Southeast Asia, and Oceania is restricted, while Australia and America are completely beyond its scope. On the other hand, even in Nuclear Eurasia where the system is quite working there are many narrative episodes that are still unnoticed and unindexed. As a whole, these 
episodes have a wide distribution but specifically in Europe they are not attested or scarce, and therefore have not been numbered in ATU.

The lack of progress in cataloguing international tale-types owes to the fact that the work obtains its importance only if folklore is assumed to be a source of data on the human past; otherwise, this work is of secondary value. So it is not surprising that in the last few decades the challenge of studying the areal distribution of motifs and plots has been issued exclusively by specialists who got into folkloristics from other fields of research.

Elements of culture do not spread itself and do not arise spontaneously (similar ones could emerge in traditions that are historically independent of each other but the similarity is always incomplete and often superficial). The presence of compound texts closely resembling each other at opposite ends of the ecumene is an evidence for links between the people, whether it is migrations or cultural contacts. Our goal is to reveal these links and to examine them in historical perspective. ${ }^{1}$

\section{THE CAPTIVE KHAN AND HIS DAUGHTER-IN-LAW}

The collection of folklore records made by Grigory Potanin in South Siberia and Mongolia in the late 1870s contains the following text.

Teleuts. Yeren Chechen wanted his foolish son to marry a clever girl. When it was raining, a girl got undressed, covered firewood with the clothes and her breast with her arms. She explained to Yeren Chechen that her parents are old, and she should kindle a fire just after returning home; her genitals had been seen by her father and mother, but nobody had laid eyes on her breast. Yeren Chechen understood the girl was clever, and married off his son to her. Yara Chechen, to whom Yeren Chechen submitted, had wanted to get his daughter-inlaw and so gave him impossible tasks. First of them was to make boots of stone. The daughter-in-law made a heap of sand and said to Yara Chechen that Yeren Chechen has asked her to make a rope of sand. Yara Chechen doubted whether it was a feasible task. The daughter-in-law asked him whether it was possible to make boots of stone. Afterwards Yara Chechen gave to Yeren Chechen a bull and said: "I will visit you after three days. Let the bull calve at the moment; you will entertain me with his milk". After three days, the daughter-in-law started to pluck and heap grass. She said to Yara Chechen that her father-inlaw would give birth to a child, so one should spread grass under him. Yara Chechen doubted that a man could do it. The daughter-in-law asked whether it was possible that a bull would calve. Afterwards Yara Chechen ordered Yeren Chechen to visit him neither in a shirt nor naked, neither on a horse nor 
afoot, neither going on a road nor going without a road, neither entering his yurt nor staying outside it. The daughter-in-law explained to Yeren Chechen how to cope with the task: he should wrap himself with a net, ride a stick, go betwixt the furrows and stay in the doorway with one leg outside and another one inside the yurt. After Yeren Chechen did it, Yara Chechen threw him into a pit and sent seven messengers to his son. They delivered the letter written by the prisoner: "I am lying on six layers of white silk, covering myself with seven silk blankets, playing checkers and drinking sweet white wine. I have seven rams at my home. You must kill six of them, put out an eye of the seventh, fracture his arm and send him back. Let the daughter-in-law read the letter". After reading the text, the son of Yeren Chechen asserted that his father lived well. The daughter-in-law explained: "The wine means tears, the silk is snow, the checkers are stars, the rams are the messengers". The son killed six of the messengers and put out an eye of the seventh. The daughter-in-law assembled troops and the survived messenger led them to Yara Chechen. He was killed, and Yeren Chechen was released (Potanin 1883, no. 100: 362-363).

The first part of the text is a variant of ATU 875 The Clever Farmgirl, but the second one does not have such a correspondence. It is based on the plot that is spread from Eastern Siberia to the Balkans and could be defined in the following manner: After an extensive search, a powerful man finds a clever wife for his son. Being captured by enemies, he sends with some of them an allegorical letter or oral message for his daughter-in-law. She understands the real meaning of the text, destroys the enemies and releases her father-in-law.

In Asia the plot is also attested among the northern Yakuts (Illarionov et al. 2008, no. 36: 358-363; Ksenofontov 1992, no. 27: 283-285), western Buryats (Bardakhanova \& Gympilova 2008, nos. 24-25, 27-28, 32: 122-129, 130-137, 153-154; Eliasov 1959: 7-19; Khangalov \& Zatopliaev 1889, no. 14: 86-92), Khalkha and Ordos Mongols (Dulam \& Molomjamts 2010: 37-38; Mikhailov 1962: 78-86; Potanin 1893, no. 19: 178-179), different groups of the Tuvinians (Samdan 1994, no. 9: 307-321; Taube 1994, no. 39: 255-258), the Chelkans (Sadalova 2002, no. 35: 347-355, 427), Kazakhs (Daurenbekov 1979: 193-195), Kirghiz (Brudny \& Eshmambetov 1968: 87-97), and Karakalpaks (Volkov \& Maiorov 1959: 140-142). In the Caucasus and adjacent territories it is known to the Kalmyks (Yegorov 1978: 19-31), Ossetians (Britaev \& Kaloev 1959: 348-356), Kabardians (Alieva \& Kardanguschev 1977: 21-26), Abazins (Tugov 1985, no. 80: 255-257), and Abkhazians (Bgazhba 1983: 238-245). Here are some abstracts of the texts.

Yakuts (Olenyoksky District). An old man left his foolish son at home, went down the river and came into a hut. There lived a girl with her father. When she put food in front of the guest, he asked: "How many ladles did you pour in 
my plate?" - "If you said how many steps were made by your deer on the way from home to this place, I would give you the answer," said the girl. The old man understood that she was clever and came the next day with his son. They got married. During a hunt, the old man encountered people from a hostile clan. He was caught and tied to a tilted larch. The enemies decided to kill him by the smoke of the fire. The old man asked to pass on a message to his son: "I am exhausted. I am rolling as a cone and fighting young leaves. When you have heard my words, cut down the tops of two birch trees growing right in the north, and then fix your eyes on the west. There will probably be a pine forest with countless trees. Cut down tops of all of them and bring them to me. If you do not know how to cut them, the white stone lying under my bed will help you. If you could not understand these words, the sharp knife lying under your pillow will assist you". The enemy leader sent two warriors to the home of the old man. They passed on the message to his son and daughter-in-law. She explained to him: "I am exhausted. I am rolling as a cone and fighting young leaves means that your father is tied by enemies to a tilted tree. Cut down the tops of two birch trees growing right in the north means that you must behead the warriors who came to our home. Fasten your eyes on the west. There will probably be a pine forest with countless trees. Cut down tops of all of them means that you must destroy all enemy forces. The white stone lying under my bed is your father's sword. The sharp knife lying under your pillow is me, your clever wife". The son snatched out the sword, beheaded the messengers, killed all the enemies and saved his father (Illarionov et al. 2008, no. 36: 358-363).

Kirghiz. During a journey, Zheerenche-chechen asked his son to cook the food on the horse's mane and to shorten the way. The son set the mane on fire and tried to level the road by a hoe. Zheerenche-chechen explained that he ought to have taken out the food and eaten it, having not dismounted the horse, as well as to have started an interesting conversation. Thereafter, Zheerenchechechen set out in search of a clever wife for the son. He met girls who carried off handfuls of brushwood. When the rain started, they all scattered and only Karachach covered brushwood with her robe. Zheerenche-chechen married her off to his son. After awhile Zhanybek-khan ordered Zheerenche-chechen to visit him neither afoot nor on a horse, neither going on a road nor going on a field. Karachach advised him to ride a goat and to go between two roads. Zhanybekkhan told Zheerenche-chechen to pull out sinews from a stone and to make boots of sand. Karachach, under the guise of another woman, asked the khan the same thing, and he said that it was impossible to accomplish. Thereafter, Zhanybek-khan captured Zheerenche-chechen and his son. Zheerenche-chechen sent a letter home, saying that crops had to be reaped before the beginning of the winter, the black blind goat had to be thrown into a lake, and the goat with 
straight horns had to become the leader. He also wrote that he had a sharp knife and a worthless one, and said not to forget the latter nevertheless. Karachach clarified: the enemies must be killed, Zhanybek-khan must be thrown into a lake, his place must be taken by his younger brother Berdibek, the sharp knife is she, the daughter-in-law, and the worthless knife is her husband. All this was done, and Zheerenche-chechen was released (Brudny \& Eshmambetov 1968: 87-97).

Ossetians. An aldar (noble) married his son to a daughter of another aldar, and wanted to test her. During a journey, he asked the son to shorten the road. The youth did not understand the meaning of the request, and so the father beat him. At home the daughter-in-law took pity on her husband. The aldar heard these words and expelled her. The same situation was repeated with the new daughter-in-law after the aldar had asked his son to boil a caldron without water. Then the aldar ordered the son to sell a ram and to bring back both its halves. The girl told her old mother to buy the ram, to slaughter and eat it, and to split its head into two halves and give them back to the youth (as it is the share of old men). The aldar was pleased and married his son to the girl. When he beat him once again - this time for misunderstanding the order "to make horses bold" - the new wife explained that it was necessary to let the horses graze. She also clarified the previous requests: in the first case, the youth ought to have started a conversation, while in the second one he ought to have lit the father's pipe. Later on, the aldar was captured by enemies and thrown into a pit. He suggested to hold him for ransom and to send a message to his home. It contained the following directions: bring in $18 \times 18$ one-horned bulls and as many two-horned ones, take knives away from the wall and sharpen them on an outdoor grinding stone, cut down two of three gold poles, keep the third one safe and bring it here with cattle. The daughter-in-law explained that the one-horned bulls were spearmen, two-horned ones were warriors with shields and swords, knives were the people of the aldar, and the grinding stone was she, the daughter-in-law. She also clarified that two of the envoys had to be killed, and the third one would show the way. The enemies were destroyed and the aldar was released (Britaev \& Kaloev 1959: 348-356).

Besides Siberia, Central Asia, and the North Caucasus, the same plot is attested among the Bulgarians. We have found it in Ukrainian translation. In the highly detailed Bulgarian tale-type index (Daskalova-Perkovska et al. 1994) this plot is not reflected.

Bulgarians. A wealthy man gave his son three hundred sheep, but did not give money for their maintenance and said to bring them back alive and healthy after wintering. A girl advised the youth to borrow money and to feed the sheep till the spring, then to shear wool, sell it, and repay the debt as well as the cattle. The wealthy man learned about this and went to make a proposal to the girl to 
marry his son. When he asked her about her father, she said to him: "He went to the mill. If he goes around the forest, he will come back soon, and if he goes straight, he will be delayed". Shortly after the girl's father came home. He said that he would give his daughter, but demanded to bring matchmakers. When they came and sat at the table, a dog began to bark outside. The father-in-law went out to see who is coming and, having returned, said: "A neroda goes. He leads a neploda and carries nenitca". ${ }^{2}$ The girl clarified: "A monk went. He led a mule and carried salt". When the newly married couple set out, the fatherin-law told them to wait for him at straight furrows and dry stumps emitting water. During the journey, the girl explained that they ought to wait near the vineyard. One day, the father-in-law was captured by robbers. He said to them: "Go to my home and tell my daughter-in-law to feed you and give you something to drink. Let her lead you into the cellar where money is kept. You will be able to take as much as you want. I also ask you to communicate to my daughter-in-law the following words: our dog has brought puppies and our sow has farrowed, so take the puppies and throw them under the sow and put the piglets under the dog". The daughter-in-law listened to the message, fed the robbers and gave them to drink, and then said: "Here's the piglets under the dog and the puppies under the pig!" Peasants killed the robbers and released the father-in-law (Ketkov 1979: 151-153).

The records that were retold here and other texts based on the plot contain a whole set of similar episodes: a man asks his son to shorten the way (i.e. to start a conversation) and/or to sell a sheep and to bring back both the animal and the value (a girl teaches the youth how to cope with the task); when the rain starts, girls scatter and one of them covers firewood with her clothes (a man seeking a wife for his son sees that she is clever); all or a few envoys sent by enemies are killed; when naming certain species of domestic animals the captive has in mind certain people.

The texts are not only obviously resembling each other but also attested on territories with similar natural environment. All of these records, with the exception of the Yakut tale, are taken in the Eurasian steppe belt and adjoining mountainous areas, from Lake Baikal to the Balkans (Figure 1.1). In the following, we will call this set of texts Variant 1 (The Captive Khan and His Daughter-in-Law). There are also other groups of tales as well as specific single records that share some similar traits with Variant 1 and are dealing with one common theme. It could be named The Encoded Message and defined in such a way: One of the members of a family gets into trouble and sends to the relatives a text or an object (father-in-law to daughter-in-law, daughter-in-law to father-in-law, husband to wife). Only the receiver understands the real meaning of the message, saves the sender and/or destroys the enemies. 


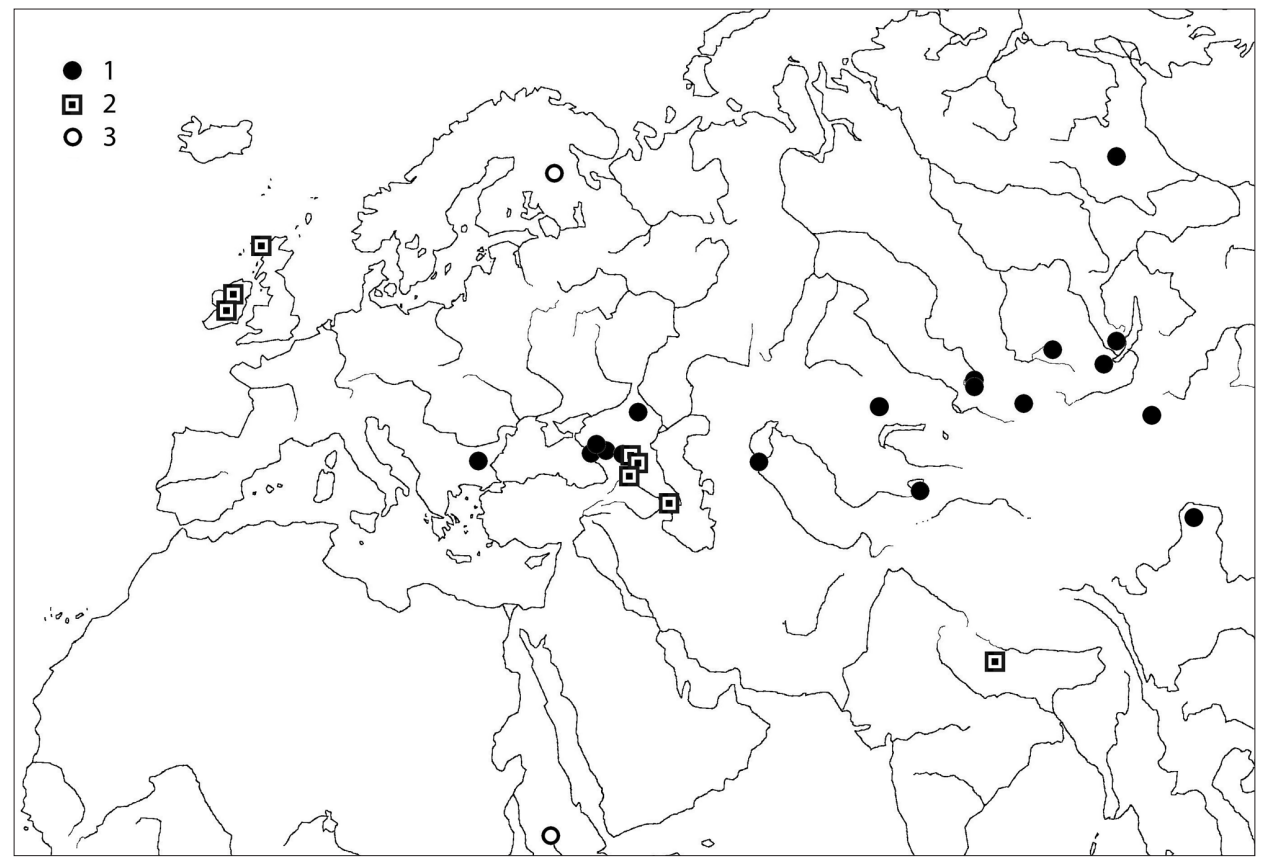

Figure 1. Distribution of "The Encoded Message". 1. "The Captive Khan and His Daughter-in-Law". 2. "The Crooked Tower and the Builder's Daughter-in-Law". 3. Karelian and Amharan versions related to Variant 1.

\section{THE CROOKED TOWER AND THE BUILDER'S DAUGHTER-IN-LAW}

Variant 2 is close to Variant 1 but attested in other areas (Figure 1.2). We will call it The Crooked Tower and the Builder's Daughter-in-Law. A master builder gets to know that a king is going to kill or maim him. He asks the king to send a messenger to his home to bring some ostensibly forgotten objects, usually a special tool. His daughter-in-law or wife understands the real meaning of the message, takes the envoy - in most of versions it is the king's son - hostage and saves the builder.

This variant is very popular among the Irish (Davies 1859: 106-109; Greene 1909: 172-174; Gregory 1905-1906: 75-76; Kelly 1999: 23-27; Kennedy 1866: 68-72; Mac Gréine 1930, no. 4: 262-263; Ó Cianáin 1933: 164-166) and Gaels, including Gaelic-speaking communities of the Outer Hebrides and Cape Breton (MacDougall 1957; MacIntyre 1966; MacLellan 1959; MacNeil 1987, no. 15: 58-60, 243-244). ${ }^{3}$ The main figure of all these stories is the legendary carpenter and architect Gobán (or Boban) Saor. 
At the same time, the plot is registered in South Asia among the Nepalese (Sakya \& Griffith 1980: 127-129) and in the Caucasus among the Ingush (Malsagov 1983, no. 58: 208-210), Chechens (Malsagov 1983: 345; Rossikova 1896, no. 3: 220-222), Georgians (Chikovani 1954, no. 66: 325-327; Kurdovanidze 1988, no. 110: 194-195), and Azerbaijanis (Seidov 1983: 139-144). In the Azerbaijani version, the shah sends to the builder's wife a messenger, a vizier, and, eventually, goes to her personally.

The vast geographical scattering (from the British Isles to Nepal) indicates that some of the texts could remain unknown to us. Nevertheless, even those records that are the most remote from each other have much in common. In the North Caucasus, the border between Variant 1 and Variant 2 separates, on the one hand, speakers of the Northwest Caucasian languages and the Ossetians, and, on the other, speakers of the Northeast Caucasian, namely the Nakh, languages, the Georgians and the Azerbaijanis. Here are some abstracts of these tales.

Gaels (North Uist). Boban Saor sent his son to the market with wethers. He had to get a shilling for them and the wethers back. They were not sold but, on the way back, a girl took them and sheared them, and then gave them back. Boban advised his son to marry this girl, which he did. Then Boban and his son went to Ireland to build a castle and the son's wife advised him to make friends with a girl there. They built the castle but the son's girlfriend told him they were planning to kill them instead of paying them. Boban advised the lord that there was a crack in the wall that could not be fixed without a special tool that he had at home. The lord refused to let them go but allowed his own son to go. Boban's wife understood the message and kept him prisoner till Boban and his son were paid and allowed home safely (MacDougall 1957).

Irish (County Longford). A king wanted to build a tower, so he sent for Gobán Saor. Gobán came with his son and began the work. When the tower was nearly completed, Gobán got a hint that the king was going to make him and his son prisoners, for the fear that anyone else would have another tower like his. Gobán told him that he wanted a special tool to finish the tower, and that his wife wouldn't give it to anyone but himself or his son, for it was a secret. The king refused to let them go but sent his own son. Gobán told the prince to ask his wife for "the crooked and the straight", and to be very careful when bringing it back with him. The prince got to Gobán's house and passed on the message to his wife. The wife said that she would get the tool, and went to a big chest and raised up the lid. She asked the prince to help her. He stuck his head into the chest, and when he did it, Gobán's wife upended him into it and clapped down the lid. Then she sent word to Gobán that she had the prince, and when Gobán went and told the king how he had put him in a fix, he had to let him go (Mac Gréine 1930, no. 4: 262-263). 
Ingush. During a journey, an old builder asked his son to shorten the way and to bring a horse. The son did not understand and failed to respond to the requests. "So let's go back home. When we get there, you have to divorce your wife," said the old man. The situation was repeated several times. At long last, the builder's son married a clever girl. She explained that "to shorten the way" means to start a conversation, and "to bring a horse" means to give a staff. Some time later the old man and his son began to build a tower for a king. The builder forefelt that the king would want to kill them instead of paying them, so he had asked his son to start a relationship with the king's daughter. When the tower was almost ready, she alarmed the builders that the king was actually going to kill them. The old man continued the work and intentionally made the top of the tower crooked. Then he told the king that the walls could be straightened by a lever that he had at home. The king sent his son and a servant to fetch it. The builder asked them to pass on a message to his daughter-in-law: "The top of the tower we are building is crooked. Send a lever for straightening towers. Let the crow out of the house, and keep the falcon locked up until our return". The daughter-in-law understood the message and explained its meaning to the relatives. They imprisoned the prince, and sent the servant back. The king had to pay the builders in full and let them go. After they got home, the prince was released (Malsagov 1983, no. 58: 208-210).

Nepalese. A carpenter asked his youngest son to kill a sheep and to bring back goods on it. A girl explained that the father meant to sell the sheep at the market and to buy goods with the money. The carpenter married his son to that clever girl. When the king undertook the construction of a great temple, the father with his three sons went there to find jobs. On the way, he asked them to cut down the mountain. All his sons were shocked and he told them to return home. Only the wife of the youngest son was able to explain that the father meant to tell stories. The next day, the carpenter took his sons to the same spot and repeated the request. The youngest started to tell a story. They arrived in the next country and built the most beautiful pagoda. The king decided to cut off the builders' hands in order that such a temple would never again be built anywhere. The carpenter told the king that they had sent their hands home and that his youngest daughter-in-law was storing those skilled hands there. The king sent his men to fetch the hands but the daughter-in-law told them that she could give them only to the king's son. When the prince arrived, she locked him in a room deep in the basement and sent a messenger to the king: if he cut off any of those men's hands, she will cut off the hands of his son. The king let the builders go back to their home with the rightful reward and the prince returned unharmed (Sakya \& Griffith 1980: 127-129). 


\section{RARE VERSIONS}

Among rare versions of The Encoded Message, the most significant are Karelian and Amharic tales (Figure 1.3). Both are closer to Variant 1 than to Variant 2, but, at the same time, have some peculiar traits. In the Karelian tale, not the daughter-in-law saves her father-in-law, but the father-in-law rescues the wife of his son. In the Amharic record, the woman understands the allegorical message and kills the robbers, but they have time to murder her husband, so she finds only his remains.

Karelians (Kalevalsky District). A woman told her son to find a bride in the house where the stove would be lighted earlier than in the rest. The youth came into the house and saw a girl dressed in a chemise and engaged in weaving. She asked him why he had neither mouth nor nose, and told him to tie the horse to winter or summer (they are both in the yard). She also said that her father went for heat, the mother was sick with a last year's merriment, and the brother was going back and forth. The youth did not understand her words, returned home and began to complain that the girl was beautiful but stupid. The father explained that before entering the house he ought to cough; there were a cart and a sledge in the yard; the girl's father went for firewood, her mother gave birth to a child, and the brother was ploughing. After that, the youth married this girl. His father took him into the forest and, when they were going back home, said to him: "Cut off my head and hands, and also throw sticks on the road in order to shorten the way". The son thought the old man had gone out of his mind. At home, he told his wife about it; she explained that he ought to have taken the father's cap and mittens, as well as to have started a conversation. After learning about the girl's cleverness, a king took her away. The old man sent a message to her, saying: "Do you dress well, or do you sometimes wear ragged clothes?" - "On Saturday evenings, the pinafore is ragged," replied the girl. The old man understood that on these evenings the back gate is opened, went there and returned his daughter-in-law (Konkka 1963, no. 58: 374-378).

Amhara. (We omit initial episodes here as they are not directly related to the subject matter). A man together with a rich man were walking along the road. When they were climbing a hill or coming down it, he proposed to the rich man to carry each other in turn. Furthermore, he called small villages with many people "cities", while large but lonely ones "small hamlets". When the rich man got home, he told his relatives about the strange companion. The daughter explained that the companion had proposed to tell stories, and that a village was a town if there was a judge and a mayor. The rich man invited him into his home. The companion demanded that the rich man's daughter become his wife and asked her to sow, grow, and process cotton, and to make clothes from it during a day. The girl told him to grow chickpea and to prepare 
oil from it during the same time period. After that they got married. The man left a note and disappeared. There were only two words there - "seven" and "hundred". The girl told her parents that it meant "in the seventh month, I will come with my relatives. There will be one hundred people". After returning, the man carried gold from one place to another and was captured by robbers. They began to consult what was best to be done, to kill him or let him go. A robber that was toothless proposed to leave him alive, but the others decided to slay him. Before his death, the man advised the robbers to visit his home (he had some good wine there) and asked them to say to his wife: "There are seven jugs of wine. Keep the one that has jagged edges, and put the others before them". The wife understood the message and called people for help. The robbers were captured, six of them were killed, the toothless was left alive and told to show the place where the body of the dead man lay (Gankin 1979, no. 116: 159-163).

There are also texts that contain only some episodes of The Encoded Message. One such example can be found in early Arabic literature. The captive there sends an allegorical message not in order to save himself but in order to rescue people of his tribe. A similar situation occurs in Yakut historical legends.

Arabs (Days of the Arabs, second half of the first millennium A.D.). Warriors of the Banu Bakr b. Wa'il tribe decided to attack people of the Banu Tamim tribe. A man named One-eye who was a member of the Banu Tamim and was at that time a captive of the Banu Bakr had learned about this and asked to send a message to his relatives. A youth was brought to him. One-eye took some sand in his hand and asked: "How much sand is there in my hand?" "There is an innumerable multitude there," replied the youth. One-eye pointed at the sun and asked one more question: "What is it?" - "The sun," was the answer. "You are a quick-witted fellow," said One-eye, "go to my relatives and give them my regards. Tell them to treat their captive from the Banu Bakr well, as the people here are treating me like this. Tell them also to unsaddle my red camel and to ride my brown female camel, remembering that I ate hais with them. They should take care of my affairs among Malik's sons. Let them know that blackthorn was covered with leaves, and women made bota bags. They should listen to Khuzail b. al-Akhnas". The youth delivered the message. One-eye's relatives did not understand his words and thought that he had gone mad. Khuzail explained to them: "Taking the sand in his hand, he wanted to say that an innumerable army is moving towards you. Pointing at the sun, he said that it is clearer than the sun. His red camel is Mount Al-Samman, and he tells you to unsaddle him, that is, to get away from this mountain. His brown female camel is the ad-Dahna desert, and he tells you to take cover there. Speaking about Malik's sons, he wants you to warn them about what he had told you, and hold an alliance with them. The blackthorn covered with leaves means that the enemies armed themselves. The women made bota bags for the march. Talking 
about hais, he has in mind that several clans have assembled to take part in this campaign against you (as hais is made from dates, ghee, and curd)". People of the Banu Tamim tribe went to the ad-Dahna desert, and alarmed the Banu Malik b. Hanzalah (Dolinina \& Polosin 1983: 112-114).

Yakuts (Vilyuysky District). Mangan Mekchi and his warriors attacked Yungkeebil Khosuun. Before his death, he said: "Let my old father turn toward the east and shoot an arrow from my bow". The warriors delivered the message. Yungkeebil Khosuun's father surmised its meaning, snatched the cradle with his grandson and threw it into a pit wherefrom the soil was taken. The warriors did not notice this and went away. When the son of Yungkeebil Khosuun grew up, he killed Mangan Mekchi as well as his people (Ergis 1960, no. 23: 109-111).

Sometimes the motif of a clever woman who understands the real meaning of her husband's message is incorporated into the tales based on The Wife Who Would Not Be Beaten (ATU 888A). Here are corresponding episodes of such an Indian text.

Uttar Pradesh (data on ethnic affiliation are lacking). A merchant's son announced that he would marry only a woman who would allow him to beat her every day. After the wedding his wife said that she would permit him to beat her if he earned money and bought things for their home. The merchant's son set out on a trading expedition, but during the journey encountered some cheaters and lost all his goods. As a result, he had to get fixed up in a job at a dairy. He sat at a press and squeezed oil out of sesame seeds for days on end. Nevertheless, he wrote to his father that he was glad of his destiny and had accumulated great wealth in his hands. The merchant was very pleased, but the wife of his son understood that everything that was written in the letter was a fiction. She disguised herself as a man and helped her husband to return home (Zograf 1976: 218-223).

\section{KING THE CRAFTSMAN AND THE BASKET MAKER}

The ATU index includes The Basket Maker tale-type (888A*) and defines it in the following manner: A man learns a trade (basket-making, painting) in order to support a wife. She is taken away by a sea captain. Years later, she recognises her husband when she sees his baskets displayed. It seems that such a subvariant is typical only for Europe to the west of the River Don while Central Asian, Caucasian, Near Eastern and North African cases are somewhat different. We will call this second type King the Craftsman. It includes the following episodes: A poor girl agrees to marry a prince or a king only if he learns a craft. He does it, marries the girl and then gets into the hands of robbers. He promises them to produce a valuable object that they could sell for good money. His wife or (in 
rare cases) his father recognises his work or reads secret signs on the object. The captive is released, and the criminals are killed.

This story is registered among different Arabic- and Berber-speaking groups of North Africa (Alarcón y Santón 1913, no. 3: 97-103; Nowak 1969, no. 267: 254-255), the Persian (Marzolph 1984, no. *888B: 161), Tajiks (Amonov \& Ulug-zade 1957: 352-354), Uzbeks (Afzalov et al. 1972: 445-447), Anatolian Turks (Eberhard \& Boratav 1953, no. 231: 278), Armenians (Buniatov 1898, no. 7: 107-109; Gullakian 1990: 40; Harutyunian 1986: 138-140), Georgians (Chikovani 1954, no. 72: 345-346; Kurdovanidze 1988, no. 118: 227-232), Tats (Kukullu 1974, no. 33: 250-256), Lezgins (Alieva 2013, no. 16: 82-83), Avars (Alieva 2013, no. 55: 250-251), Dargins (Alieva 2013, no. 20: 93-94), Kabardians (Tambiev 1900, no. 1: 1-8), and Volga Tatars (Zamaletdinov 2009, no. 62: 251-255). It is also found in the Wortley-Montague manuscript of the Arabian Nights (Marzolph \& Leeuwen 2004: 416), which is dated 1764-1765 and comes from Northern Egypt (Moussa-Mahmoud 1976: 7-17). The easternmost versions are recorded among the Kazakhs (Sidelnikov 1964: 116-119) and Dungans (Riftin et al. 1977, no. 49: 233-235) (Figure 2).

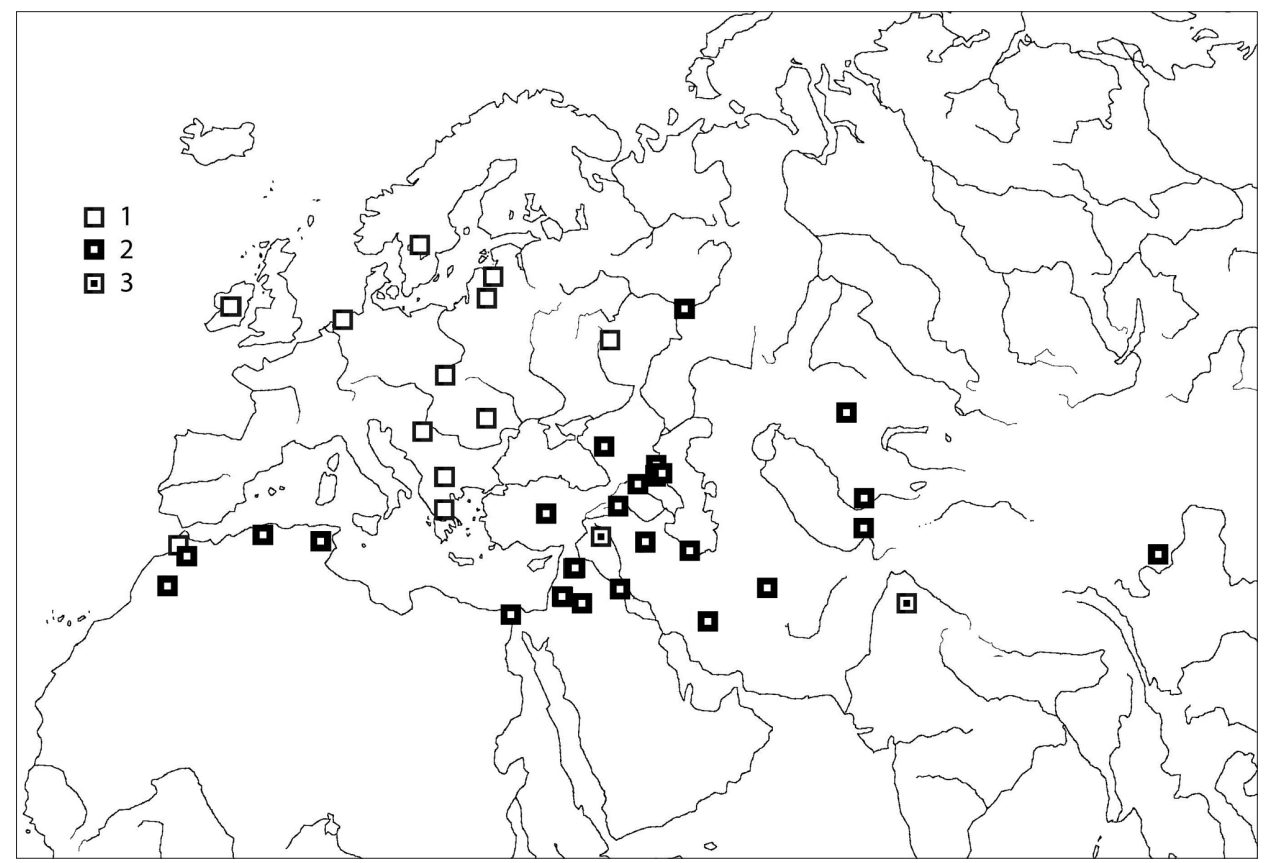

Figure 2. Distribution of "King the Craftsman" and "The Basket Maker". 1. "The Basket Maker" (ATU 888A*). 2. "King the Craftsman" (El-Shamy 2004, no. 949*). 3. Either subvariant 1 or 2 (text or detailed enough abstract are unavailable). 
Most of the European tales cited under ATU $888 \mathrm{~A}^{*}$ still remain unavailable to us. Fortunately, in the Arabian index (El-Shamy 2004), the King the Craftsman is selected as a separate tale-type $949 *$ (Young Gentleman Learns Basketwork. Skill at a craft / trade saves him). Hasan El-Shamy does not provide the reader with detailed abstracts, but the sets of motifs mentioned by him under this type and type $888 \mathrm{~A}^{*}$ are different, which allows to classify stories in question with reasonable certainty. It seems that Hans-Jörg Uther was unfamiliar with the corresponding Arabian and other African as well as Asian versions of the King the Craftsman and because of this did not pay attention to the difference between two types noticed by El-Shamy. The evidence suggests that The Basket Maker is typical mostly for Europe with only one Berberian case in Morocco while the King the Craftsman has not been found in Europe to the west of the Don and is typical for Asia and Northern Africa. The first plot is rather remotely related to other versions of The Encoded Message while the second demonstrates clear parallels with The Captive Khan and The Crooked Tower.

The most common variant of the King the Craftsman is associated with carpet making. These are Dungan, Uzbek, Tajik, Persian, Volga Tatar, Tat, Lezgian, and Armenian versions, as well as one of the Georgian records.

Dungans (text collected in southeastern Kazakhstan in the dialect spoken in Gansu). A young emperor wanted to marry a poor girl. She refused him as he did not learn any craft. The emperor had mastered the art of carpet making and weaved a wonderful carpet for this girl. They got married. After a while, the emperor disguised himself as a commoner and began to travel from one city to another. During the journey, he came to a tavern. The tavern owner and his people put him in a basement in order to slaughter him for meat. The emperor convinced them that it would be more profitable to let him make an expensive carpet. When the carpet was ready, he told the tavern's owner to sell it to the emperor. The empress understood that the carpet was a work of her husband, found, and released him. After that, all robbers were killed (Riftin et al. 1977, no. 49: 233-235).

Tats. A padishah fell in love with a herder's daughter. She said she would marry him if he learned a craft. The padishah had mastered the art of carpet making and married the girl. One day he walked in the guise of a dervish, entered a tavern, and fell in the basement. The tavern owners were robbers who were selling human flesh. The padishah told them that they would get more money if he wove a carpet. When the carpet was ready, he told them to take it to a certain shop. The padishah's wife saw the carpet and went to the tavern with warriors. The padishah was released, and the robbers were beheaded (Kukullu 1974, no. 33: 250-256). 
Volga Tatars. A padishah's son wanted to marry a poor girl. She told him to learn a craft beforehand. The young padishah had mastered the art of carpet making and married the girl. After a while, he set out on a journey through his estates. He visited many places, but one day came to an unknown city and was captured by robbers. He told them to get him to their leader. This was the governor of the city. The young padishah told him that he could weave expensive carpets for sale in the padishah's palace. The governor liked this idea. When the first carpet was delivered in the palace, the wife of the vanished padishah noticed that between its patterns the name of her husband was woven. She bought the carpet and asked to bring her some more. Each following carpet had a new message concerning the padishah's misadventure. In this way, the wife learned where he was and who had captured him. When she received the tenth carpet, she ordered to equip forces. The padishah was released, and other prisoners were permitted to punish the robbers (Zamaletdinov 2009, no. 62: 251-255).

The craft that the hero learns in order to marry may be different than carpet making, but such variants are less frequent. There is, for example, mat weaving (Turkish versions and the tale from the Wortley-Montague manuscript), silk spinning (Arabic versions from North Africa), and hat making (Kazakh version).

Kazakhs. A khan's son, Idris, fell in love with a peasant's daughter called Duriya. When he asked her to marry him, she refused him as he had not learned any craft. Idris returned to his palace and learned hat-making. Duriya agreed to marry him. After the wedding, she asked Idris to make a woollen cap and taught him how to embroider patterns which meant letters and words. Some time later, Idris disguised himself as a beggar and set out on a journey. During the journey, he came in a city, entered a house, and was captured by cannibals who were living there. He said that he could make a beautiful cap and that the khan's wife (by this time Idris was already the khan) would buy this cap for good value. When the cap was ready, two of the cannibals took it to the palace. Upon looking at this cap, Duriya understood what had happened to her husband. Idris was released, and the surviving cannibals were hung (Sidelnikov 1964: 116-119).

\section{THE BIG BULL AND THE DATING OF THE DISCUSSED TALES}

The very fact that there are links between traditions in the eastern and western parts of the Eurasian steppe belt is not surprising. The only question is how they are dated. 
It is clear that the plots discussed here did not emerge in the Palaeolithic. There are no parallels for them in the New World. The Captive Khan is associated with cattle-breeding steppe tradition, while The Crooked Tower and the King the Craftsman are associated with settled culture. The third plot is, without fail, set in a city, and the second one implies the existence of power centres and permanent fortifications.

The Captive Khan is widespread in the Eurasian steppe belt and adjoining mountainous areas (Altai, central and western parts of the North Caucasus), The Crooked Tower is attested in Nepal, South Caucasus, eastern part of the North Caucasus, and on the British Isles, and the area of distribution of The Basket Maker and the King the Craftsman embraces the main territory of Nuclear Eurasia, within which many dozens of other fairy-tale and novelistic motifs are circulated. Although all these stories can be traced back to a single prototype, they were obviously distributed across different social environments and hardly at the same time.

The eastern origin of The Captive Khan is likely simply because, since the middle of the first millennium B.C., all migrations across the Great Steppe were from east to west. Where the other stories branched off from this plot or from their common prototype is hard to say. The motif of the robbers' den, in which people were slaughtered for meat or being squeezed of their fat, is found both in the east (inter alia, in the 14th-century Chinese novel Water Margin, and in the Japanese Anthology of Tales from the Past, dating back to ca. 1050 A.D.: Ikeda 1971, no. 956A: 214; Riftin 1977: 472; Shi Nai'an \& Luo Guanzhong 1981: 924), and in the west of Eurasia (ATU 956). Although the similarity of The Basket Maker with The Captive Khan is minimal, the Karelian tale has characteristic features of both of them. This may mean that during the formation of the northern version connections between variants of The Encoded Message were obvious enough.

In the Mongol-speaking world, The Captive Khan is attested among the Ordos, Khalkha, western Buryats, and Kalmyks. Taking into account the origin of the latter, we can assume that the plot is also known to the Oirats. The Kalmyk version shares exclusive parallels with the Khalkha, Buryat, and Ossetian tales. Only in these traditions, the son is trying to cut out a wooden boiler to cook food, after his father has asked (in allegorical form) to light up his pipe or roast meat on a spit.

The existence of the Yakut versions clearly related to the Mongolian tales indicates that the story was known in Inner Asia and South Siberia from at least the 12th-13th centuries, i.e. before the migration of the Yakuts to the lowlands of the middle course of the River Lena. At the end of the 16th - early 17 th century, the Kalmyks brought it from Dzungaria to the west, but they were 
hardly alone. Among the Kalmyks, The Captive Khan is relatively rare, therefore it is unclear why this very plot should have been borrowed by the population of Kazakhstan and the North Caucasus and has become popular there.

It is also not very likely that the initial spread of The Captive Khan took place during the period of the Golden Horde. In the Russian-language publications of Bashkir and Volga Tatar folklore, no parallels for this plot have been found. In Dagestan, Variant 1 and Variant 2 are lacking and there are only tales based on the King the Craftsman, although this is the area that was connected with the Golden Horde more closely than the rest of the North Caucasus.

In the texts, collected among the Yakuts, Buryats, Khalkha, Tuvinians, and Kirghiz, the captive allegorically calls his daughter-in-law 'knife' or 'scissors'. In the Caucasus a similar comparison ("stone for sharpening knives") is found only in the Ossetian version. This is an argument in favour of the claim that the initial spread of the plot took place in earlier times; namely, the second part of the first millennium A.D., i.e. during the period of intensive interaction between the Iranian-speaking steppe tribes and the Turkic-speaking nomads, moved from the east towards the west, or even as early as the first half of the first millennium B.C., when Scythian groups migrated from Inner Asia to the North Pontic area.

Evidence in favour of this hypothesis is the presence of the geographically isolated Karelian version. It differs significantly from the southern records, but, at the same time, is obviously related to Variant 1, which is typical for the steppe areas. Concerning The Encoded Message, the Karelian parallel is unique, but there are many other plots and motifs that link up the Caucasus and the steppe zone, on the one hand, and Northern Europe, on the other. For reasons of space, it is not possible to discuss these data in detail here, so we will give only one example, The Big Bull motif (Figure 3).

The ATU tale-type 1960A with a similar name is a conglomerate of any references to domestic and wild animals of enormous size. The unique Olonets bylina tells of a giant bull, which is killed and cut up (Hilferding 1983: 286-291). This motif is also found in Balto-Finnic runic poetry, particularly in the Estonian, Ingrian, Finnish, and Karelian epic (Abercromby 1893, no. 48g: 45-46; Laugaste 1998: 9; Kiuru 1990, no. 8: 47-48; Siig 2013: 22-35; Tedre 1969, no. 4: 17; Yevseev 1950, no. 65: 146). In contrast to the bylina, the Balto-Finnic variants typically contain the motif of determination of the size of the bull by reference to the time during which an animal or bird overcomes the distance from one part of the body to another. A similar motif (the time that it takes for an unmounted man or a horseman to walk or ride from the tail to the middle of the body and from the middle to the head) is attested in the Caucasus and the steppe zone, particularly among the Gagauz, Moldovans, Adyghe, Kabardians, 


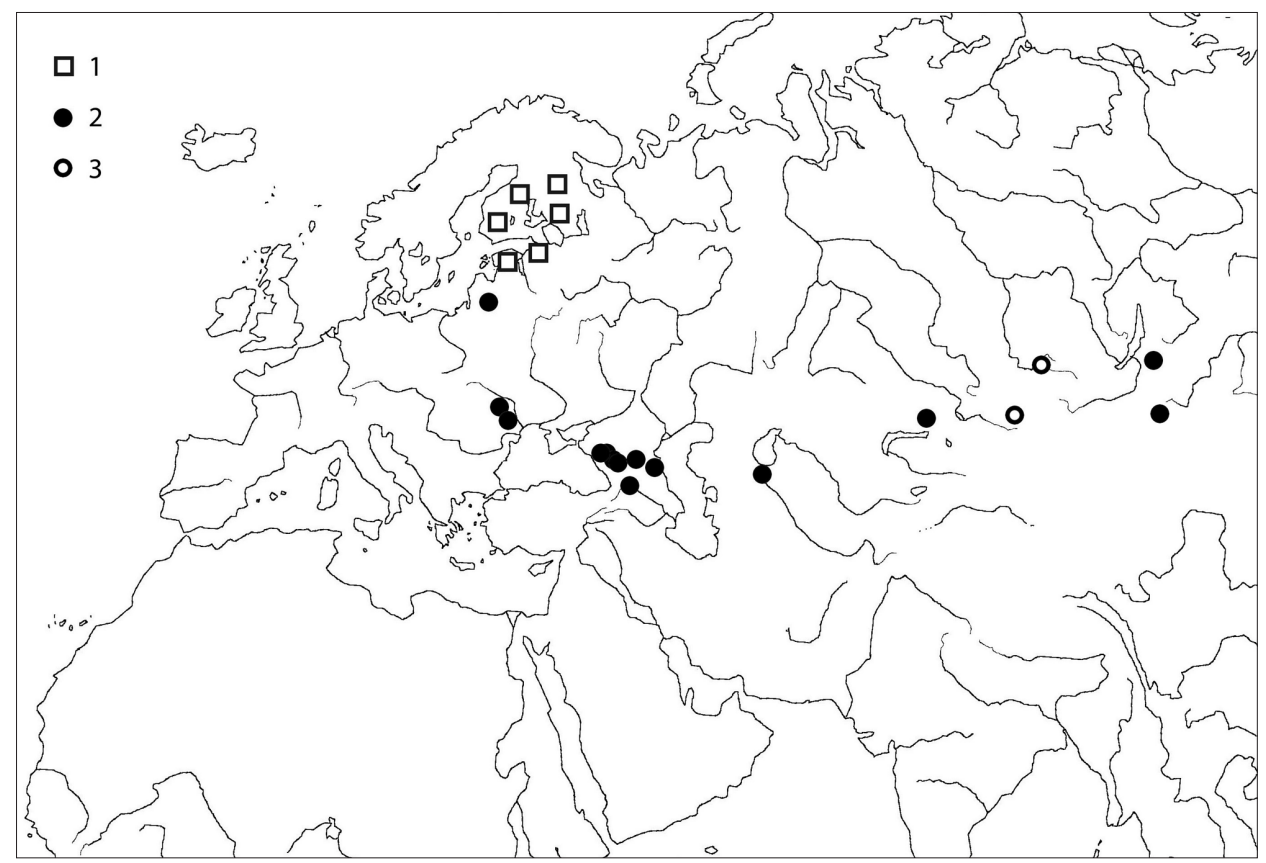

Figure 3. Distribution of "The Big Bull". 1. Balto-Finnic versions. 2. Typical southern versions. 3. Tuvinian versions.

Karachays and/or Balkars, Nogais, Georgians, Kazakhs, Karakalpaks, Khorin Buryats and Khalkha Mongols, as well as among the Lithuanians (Alieva 1978, nos. 25-26: 223-227; Alieva \& Kardangushev 1977: 123-125; Alieva \& Kholaev 1983: 90-97; Benningsen 1912: 18-19; Botezatu 1981: 368-371; Chikovani 1954: 409-410; Kerashev 1957: 271-272; Liobytè 1965: 277-278; Lopatinski 1891: 93-96; Moshkov 1904, no. 136: 204-205; Nogai 1979, no. 18: 86-102; Potanin 1893, no. 4: 378). In the Lithuanian as well as in all steppe and Caucasian versions, this episode is followed by a standard series of other ones: an eagle takes away the bull, sits down on a goat's horns and drops the bull's scapula into an old man's eye, somebody takes this bone out of the eye, it is covered with soil and settled by people, a fox begins to pull the scapula, the people kill the fox, but cannot move her corpse, a woman or a child does it easily. The same series of episodes, but without the motif of determination of the size of the bull by reference to the time spent on the road from one place to another, is found in Abazin, Karachay, Svan, Ossetian and Ingush texts (Aleinikov 1883, no. 4: 155-157; Britaev \& Kaloev 1959: 96; Dalgat 1972: 298-299; Kibiev \& Malsagov 1981: 26-28; Palmaitis 1986: 134-137; Shanaev 1870: 14-15; Tugov 1985, no. 121: 336-337). 
In variants from Tuva, a goat appears instead of a giant bull (Samdan 1994, no. 28: 399). The record made among the Altai Tuvinians is confusing and incomplete. A bull is mentioned along with a traveller, an old man, a bird, and a goat, but the initial episode, which describes how the bull was taken away by the bird, is omitted (Taube 1994, no. 57: 276-277).

In terms of genre all variants from Finland to Mongolia are similar. They can be easily integrated into different contexts, and, taken in isolation, are closely related to cumulative and tall tales. An important common motif is the paradoxical characteristic of beings and objects as simultaneously giant and tiny, mighty and weak. This also applies to most other 'Balto-Caucasian' plots that we do not consider here.

The area of distribution of The Big Bull in its southern variant largely coincides with that of The Captive Khan and His Clever Daughter-in-Law. One should note that both plots are completely lacking in the Volga region. Based only on the data presented here, it is not possible to determine the exact time of their penetration into Northern Europe, but, as has been said, there are many other parallels as well. Most of them have the distribution, which is broken up into two unconnected areas - Caucasus and the Great Steppe, on the one hand, and the Circum-Baltic region, on the other. It is logical to assume that the transfer of folklore over long distances was most easily carried out during the period of a drastic alteration of the ethnocultural map of both Europe and the Asian steppe, i.e. in the period from Late Antiquity to the Mongol invasion. A more narrow range that may be proposed for the time being is the second part of the first millennium A.D.

\section{ACKNOWLEDGEMENTS}

The work is supported by the Russian Science Foundation, project 14-18-03384 ('Stories Retold over Millennia: Reconstruction of the Dynamics of the Global Distribution of Replicated Elements of Oral Narratives').

\section{NOTES}

1 The study is based on the electronic catalogue of world folklore and mythology. On April 7, 2016, the database contained more than 50,000 abstracts of texts providing information on the spread of 2120 motifs according to 925 traditions. Its online version is updated once a year and available (in Russian) at http://www.ruthenia.ru/folklore/ berezkin. 
${ }^{2}$ Neroda, neploda, and nenitca are dialect names for 'monk', 'mule', and 'salt' correspondingly.

3 The text collected by Mrs Gomme from an old woman at Deptford and published in Jacobs' More English Fairy Tales (1894: 54-55) has more likely a Goidelic origin too.

\section{REFERENCES}

Aarne, Antti 1910. Verzeichnis der Märchentypen. Helsinki: Academia Scientiarum Fennica. (Folklore Fellows' Communication, Vol. 3).

Aarne, Antti \& Thompson, Stith 1961. The Types of the Folktale: A Classification and Bibliography. Folklore Fellows' Communication, Vol. 184. Helsinki: Academia Scientiarum Fennica.

Abercromby, John 1893. Magic Songs of the Finns. Folk-Lore, Vol. 4, No. 1, pp. 27-49. Afzalov, Mansur \& Rasulev, Kh. \& Khusainova, Z. 1972. Uzbekskie narodnye skazki. [Uzbek Folktales.] Vol. 1. Tashkent: Izdatel'stvo literatury i iskusstva.

Alarcón y Santón, Maximiliano 1913. Textos árabes en dialecto vulgar de Larache. Madrid: Imprenta Ibérica.

Aleinikov, Moisei 1883. Karachaevskie skazaniia. [Karachay Legends and Tales.] Sbornik materialov dlia opisaniia mestnostei i plemen Kavkaza, Vol. 3, Part 2, pp. 138-168.

Alieva, Alla 1978. Skazki adygskikh narodov. [Folktales of Adyghe Peoples.] Moscow: Nauka.

Alieva, Fatima 2013. Svod pamiatnikov fol'klora narodov Dagestana. [Corpus of Folklore Records of the Peoples of Dagestan.] Vol. 3. Bytovye skazki [Realistic Tales.] Moscow: Nauka.

Alieva, A. \& Kholaev, A. 1983. Balkarskie i karachaevsckie skazki. [Balkar and Karachay Folktales.] Moscow: Detskaia literatura.

Alieva, A. \& Kardanguschev, Z. 1977. Kabardinskie narodnye skazki. [Kabardian Folktales.] Moscow: Detskaia literatura.

Amonov, Rajab \& Ulug-zade, Klavdia 1957. Tadjikskie narodnye skazki. [Tajik Folktales.] Stalinabad: Tajikgosizdat.

Bardakhanova, Svetlana \& Gympilova, Sesegma 2008. Buriatskie narodnye skazki. Volshebnye. Bytovye. [Buryat Fairy and Realistic Tales.] Ulan-Ude: Izdatel'stvo Buriatskogo nauchnogo tsentra.

Benningsen, Adam 1912. Legendy i skazki Tsentralnoi Azii, sobrannye grafom A.P. Benningsenom. [Legends and Tales of Central Asia Collected by Count A.P. Benningsen.] Saint Petersburg: n.p.

Berezkin, Yuri 2015a. Folklore and Mythology Catalogue: Its Lay-Out and Potential for Research. The Retrospective Methods Network Newsletter, Vol. 10, pp. 56-70.

Berezkin, Yuri 2015b. Rasprostranenie fol'klornykh motivov kak obmen informatsiyei, ili Gde zapad granichit s vostokom. [Areal Spread of Folklore Motifs as Information Exchange, or about the Borderline between West and East.] Forum for Anthropology \& Culture, No. 26, pp. 153-170.

Bgazhba, Khukhut 1983. Abkhazskie skazki. [Abkhaz Folktales.] Sukhumi: Alashara. Botezatu, Grigore 1981. Moldavskie narodnye skazki. [Moldavian Folktales.] Kishinev: Literatura artistike. 
Britaev, Sozyryko \& Kaloev, G. 1959. Osetinskie narodnye skazki. [Ossetian Folktales.] Moscow: Gosudarstvennoe izdatel'stvo khudozhestvennoi literatury.

Brudny, Dmitri \& Eshmambetov, Kasymbek 1968. Kirgizskie skazki. [Kirghiz Folktales.] Moscow: Khudozhestvennaia literatura.

Buniatov, Grigory 1898. Armianskie predaniia i skazki. [Armenian Legends and Tales.] Sbornik materialov dlia opisaniia mestnostei i plemen Kavkaza, Vol. 24, Part 2, pp. 96-151.

Chikovani, Mikhail 1954. Gruzinskie narodnye skazki (sto skazok). [Georgian Folktales (One Hundred Tales).] Tbilisi: Zaria Vostoka.

Dalgat, Uzdiat 1972. Geroicheskii epos chechentsev $i$ ingushei: Issledovanie $i$ teksty. [Chechen and Ingush Heroic Epic: Study and Texts.] Moscow: Nauka.

Daskalova-Perkovska, Liliana \& Dobreva, Dorotea \& Kotseva, Yordanka \& Mitseva, Yevgenia 1994. Blgarski folklorni prikazki. Katalog. [Bulgarian Folktales. The Catalogue.] Sofia: Sv. Kliment Okhridski.

Daurenbekov, Tanash 1979. Kazakhskie narodnye skazki. [Kazakh Folktales.] AlmaAta: Zhalyn.

Davies, Francis Robert 1859. Legends of the County Clare. In: Choice Notes from "Notes and Queries": Folk Lore. London: Bell and Daldy, pp. 92-110.

Dolinina, Anna, \& Polosin, Vladimir 1983. Araviiskaia starina. Iz drevnei arabskoi poezii i prozy. [Arabian Antiquity. Selections from Ancient Arabian Poetry and Prose.] Moscow: Nauka.

Dulam, Sendenjav \& Lkhagvasüren, Molomjamts 2010. Mother Tongue, Oral Traditions. In: Urtnasan Norov (ed.). Intangible Cultural Heritage of the Mongols. Jeonju: International Information and Networking Centre for Intangible Cultural Heritage in the Asia-Pacific Region under the auspices of UNESCO, pp. 21-43.

Eberhard, Wolfram \& Boratav, Pertev Naili 1953. Typen türkischer Volksmärchen. Akademie der Wissenschaften und der Literatur. Veröffentlichungen der orientalischen Kommission. Bd. 5. Wiesbaden: Franz Steiner Verlag.

Eliasov, Lazar 1959. Altan-Khaisha - zolotye nozhnitsy. Buriatskie narodnye skazki. [Altan-Khaisha - The Gold Scissors. Buryat Folktales.] Moscow: Gosudarstvennoe izdatel'stvo detskoi literatury.

El-Shamy, Hasan M. 2004. Types of the Folktale in the Arab World: A Demographically Oriented Tale-Type Index. Bloomington: Indiana University Press.

Ergis, Georgy 1960. Istoricheskie predaniia i rasskazy yakutov. [Historical Legends and Stories of the Yakuts.] Vol. 1. Moscow and Leningrad: Izdatel'stvo Akademii nauk SSSR.

Gankin, Emmanuil 1979. Amkharskie narodnye skazki. [Amharic Folktales.] Moscow: Nauka.

Greene [Miss Greene] 1909. County Kildare Folk-Tales. Journal of the County Kildare Archaeological Society, Vol. 6, No. 2, pp. 172-174.

Gregory [Lady Gregory] 1905-1906. The Goban Saor. Journal of the Galway Archaeological and Historical Society, Vol. 4, No. 2, pp. 73-77.

Gullakian, Syuzanna 1990. Ukazatel' syuzhetov armianskikh volshebnykh i novellisticheskikh skazok. [A Type Index of Armenian Fairy and Realistic Tales.] Yerevan: Respublikanskii uchebno-nauchnyi kabinet. 
Harutyunian, Sargis 1986. Armianskie narodnye skazki. [Armenian Folktales.] Yerevan: Sovetakan grokh.

Hilferding, Alexander 1983. Onezhskie byliny. [Onega Bylinas.] Arkhangelsk: Severozapadnoe knizhnoe izdatel'stvo.

Ikeda, Hiroko 1971. A Type and Motif Index of Japanese Folk-Literature. Folklore Fellows' Communication, Vol. 209. Helsinki: Suomalainen Tiedeakatemia.

Illarionov, Vasili \& Diakonova, Yulia \& Mukhopleva, Svetlana \& Nesterova, Lytsia 2008. Yakutskie narodnye skazki. [Yakut Folktales.] Pamiatniki fol'klora narodov Sibiri i Dal'nego Vostoka, Vol. 27. Novosibirsk: Nauka.

Jacobs, Joseph 1894. More English Fairy Tales. London: David Nutt.

Kelly, Éamon 1999. Ireland's Master Storyteller: The Collected Stories. Cork: Mercier Press.

Kennedy, Patrick 1866. Legendary Fictions of the Irish Celts. London: Macmillan and Co.

Kerashev, Tembot 1957. Adygeiskie skazki. [Adyghe Folktales.] Maykop: Adygeiskoe knizhnoe izdatel'stvo.

Ketkov, Oleksandr 1979. Bolgars'ki narodni kazki. [Bulgarian Folktales.] Kiev: Veselka.

Khangalov, Matvei \& Zatopliaev, Nikolai 1889. Buriatskie skazki i poveria. [Buryat Tales and Beliefs.] Zapiski Vostochno-Sibirskogo otdela Imperatorskogo russkogo geograficheskogo obshchestva po otdeleniyu etnografii, Vol. 1, Part 1. Irkutsk: Vostochnoe obozrenie.

Kibiev, Musbek \& Malsagov, Akhmet 1981. Chechenskie i ingushskie narodnye skazki. [Chechen and Ingush Folktales.] Moscow: Detskaia literatura.

Kiuru, Eino 1990. Ingermanlandskaia epicheskaia poeziia. [Ingrian Epic Poetry.] Petrozavodsk: Karelia.

Konkka, Unelma 1963. Karel'skie narodnye skazki. [Karelian Folktales.] Moscow \& Leningrad: Izdatel'stvo Akademii nauk SSSR.

Ksenofontov, Gavriil 1992. Uraangkhai-sakhalar: Ocherki po drevnei istorii yakutov. [The Uraangkhai-Sakhalar: Essays on the Ancient History of the Yakuts.] Vol. 1, Book 2. Yakutsk: Natcional'noe knizhnoe izdatel'stvo Respubliki Sakha.

Kukullu, Amaldan 1974. Zolotoi sunduk (skazki tatov Dagestana). [The Gold Chest (Folktales of the Dagestanian Tats).] Moscow: Nauka.

Kurdovanidze, Teimuraz 1988. Gruzinskie narodnye skazki. [Georgian Folktales.] Book 2. Moscow: Nauka.

Laugaste, Eduard 1998. Suur Tamm. Allikmaterjale iseseisvaks tööks eesti keele ja kirjanduse eriala üliõpilastele. [The Big Oak.] Tartu: Tartu Riikliku Ülikooli eesti kirjanduse ja rahvaluule kateeder.

Liobyte, Aldona 1965. Koroleva Lebed'. Litovskie narodnye skazki. [The Swan Queen. Lithuanian Folktales.] Vilnius: Vago.

Lopatinski, Lev 1891. Kabardinskie predaniia, skazaniia i skazki, zapisannye po-russki. [Kabardian Legends and Tales Recorded in Russian.] Sbornik materialov dlia opisaniia mestnostei i plemen Kavkaza, Vol. 12, Part 1, pp. 1-144.

MacDougall, Donald 1957. Boban Saor and His Son Saved as a Result of the Son's Wife's Advice. School of Scottish Studies Archive SA1957.080, Tobar an Dualchais / Kist o Riches. Available at http://www.tobarandualchais.co.uk/fullrecord/42721/1, last accessed on January 22, 2016. 
Mac Gréine, Pádraig 1930. A Longford Miscellany. Béaloideas: The Journal of the Folklore of Ireland Society, Vol. 2, No. 3, pp. 261-273.

MacIntyre, Michael 1966. Boban Saor and How He Uncovered a Plan to Have Him Hanged. School of Scottish Studies Archive SA1966.084, Tobar an Dualchais / Kist o Riches. Available at http://www.tobarandualchais.co.uk/fullrecord/60776/1, last accessed on January 22, 2016.

MacLellan, Angus 1959. How Boban Saor and His Son Got Back Safely from France with the Help of His Son's Wife. School of Scottish Studies Archive SA1959.057, Tobar an Dualchais / Kist o Riches. Available at http://www.tobarandualchais. co.uk/fullrecord/41005/1, last accessed on January 22, 2016.

MacNeil, Joe Neil 1987. Tales until Dawn: The World of a Cape Breton Gaelic StoryTeller. Translated and edited by John Shaw. Kingston and Montreal: McGillQueen's University Press.

Malsagov, Akhmet 1983. Skazki i legendy ingushei i chechentsev. [Ingush and Chechen Folktales and Legends.] Moscow: Nauka.

Marzolph, Ulrich 1984. Typologie des persischen Volksmärchens. Beiruter Texte und Studien. Bd. 31. Beirut: Orient-Institut der Deutschen Morgenländischen Gesellschaft.

Marzolph, Ulrich \& Leeuwen, Richard van 2004. The Arabian Nights Encyclopedia. Santa Barbara, Denver \& Oxford: ABC-CLIO.

Mikhailov, Georgy 1962. Mongol'skie skazki. [Mongolian Folktales.] Moscow: Khudozhestvennaia literatura.

Moshkov, Valentin 1904. Narechiia bessarabskikh gagauzov. [Dialects of the Bessarabian Gagauz.] Saint Petersburg: Imperatorskaia akademiia nauk.

Moussa-Mahmoud, Fatma 1976. A Manuscript Translation of the Arabian Nights in the Beckford Papers. Journal of Arabic Literature, Vol. 7, pp. 7-23.

Nogai, Azhdaut 1979. Nogaiskie narodnye skazki. [Nogai Folktales.] Moscow: Nauka.

Nowak, Ursula 1969. Beiträge zur Typologie des arabischen Volksmärchens. InauguralDissertation zur Erlangung der Doktorwürde der Philosophischen Fakultät der Albert-Ludwig-Universität zu Freiburg im Breisgau. Freiburg im Breisgau.

Ó Cianáin, S.F. 1933. Folk Tales from Co. Sligo. Béaloideas: The Journal of the Folklore of Ireland Society, Vol. 4, No. 2, pp. 164-167.

Palmaitis, Mykolas 1986. Upper Svan: Grammar and Texts. Vilnius: Mokslas.

Potanin, Grigory 1883. Ocherki severo-zapadnoi Mongolii. [Essays on Northwestern Mongolia.] Vol. 4. Materialy etnograficheskie. [Ethnographic Materials.] Saint Petersburg: V. Kirshbaum.

Potanin, Grigory 1893. Tangutsko-tibetskaia okraina Kitaia i Tsentral'noi Mongolii. [The Tangut-Tibet Border of China and Central Mongolia.] Vol. 2. Saint Petersburg: A.S. Suvorin.

Riftin, Boris \& Khasanov, M. \& Yusupov, I. 1977. Dunganskie narodnye skazki i predaniia. [Dungan Folktales and Legends.] Moscow: Nauka.

Rossikova, Anna 1896. Puteshestvie po tcentral'noi chasti gornoi Chechni. [A Journey through the Central Part of Mountainous Chechnya.] Zapiski Kavkazskogo otdela Imperatorskogo russkogo geograficheskogo obshchestva, Vol. 18, pp. 139-228.

Sadalova, Tamara 2002. Altaiskie narodnye skazki. [Altai Folktales.] Pamiatniki fol'klora narodov Sibiri i Dal'nego Vostoka, Vol. 21. Novosibirsk: Nauka. 
Sakya, Karna \& Griffith, Linda 1980. Tales from Kathmandu. Folktales from the Himalayan Kingdom of Nepal. Brisbane: House of Kathmandu.

Samdan, Zoia 1994. Tuvinskie narodnye skazki. [Tuvinian Folktales.] Pamiatniki fol'klora narodov Sibiri i Dal'nego Vostoka, Vol. 8. Novosibirsk: Nauka.

Seidov, Nureddin 1983. Azerbaidzhanskie skazki. [Azerbaijan Folktales.] Baku: Maarif. Shanaev, Dzhantemir 1870. Osetinskie narodnye skazaniia. [Ossetian Folktales and Legends.] Sbornik svedenii o kavkazskikh gortsakh, Vol. 3, pp. 2-40.

Shi Nai'an \& Luo Guanzhong 1981. Outlaws of the Marsh. Translated by Sidney Shapiro. Vol. 2. Beijing: Foreign Languages Press.

Sidelnikov, Viktor 1964. Kazakhskie narodnye skazki. [Kazakh Folktales.] Vol. 3. AlmaAta: Kazakhskoe gosudarstvennoe izdatel'stvo khudozhestvennoi literatury.

Siig, Kristo 2013. Suure härja mü̈̈t läänemeresoome rahvaste traditsioonis ja selle ajalooline taust. [Myth of the Big Bull in the Tradition of Balto-Finnic Peoples and Its Historical Background.] Bachelor's thesis. Tartu: Tartu Ülikooli filosoofia teaduskond.

Tambiev, Pago 1900. Adygskie teksty. [Adyghe Texts.] Sbornik materialov dlia opisaniia mestnostei i plemen Kavkaza, Vol. 27, Part 4, pp. 1-62.

Taube, Erika 1994. Skazki i predaniia altaiskikh tuvintsev. [Tales and Legends of the Altai Tuvinians.] Moscow: Vostochnaia literatura.

Tedre, Ülo 1969. Eesti Rahvalaulud. Antoloogia. [Estonian Folk Songs. Anthology.] Vol. 1, fasc. 1. Tallinn: Eesti Raamat.

Tugov, Vladimir 1985. Abazinskie narodnye skazki. [Abazin Folktales.] Moscow: Nauka.

Uther, Hans-Jörg 2004. The Types of International Folktales: A Classification and Bibliography. Based on the System of Antti Aarne and Stith Thompson. Parts 1-3. Folklore Fellows' Communications, Vol. 284-286. Helsinki: Academia Scientiarum Fennica.

Volkov, A. \& Maiorov, I. 1959. Karakalpakskie narodnye skazki. [Karakalpak Folktales.] Nukus: Karakalpakskoe knizhnoe izdatel'stvo.

Yegorov, V. 1978. Kalmytskie narodnye skazki. [Kalmyk Folktales.] Elista: Kalmytskoe knizhnoe izdatel'stvo.

Yevseev, Viktor 1950. Karel'skie epicheskie pesni. [Karelian Epic Songs.] Moscow \& Leningrad: Izdatel'stvo Akademii nauk SSSR.

Zamaletdinov, Lenar 2009. Tatarskoe narodnoe tvorchestvo. [Tatar Folklore.] Vol. 3. Bytovye skazki. [Realistic Tales.] Kazan: Magarif.

Zograf, Georgy 1976. Skazki narodov Indii. [Tales of the Peoples of India.] Leningrad: Khudozhestvennaia literatura. 